Review

\title{
Formation Mechanisms, Evaluation Methods and Research Perspective of Slagging and Fouling on Pulverized Coal Combustion
}

\author{
Hirofumi TsuJ, Yoshiko HIEI, Nobuyuki WAKABAYASHI, and Hiromi SHIRAI \\ (Received February 5, 2010)
}

\section{微粉炭燃焼時のスラッギングとファウリングの発生機構, 評価法と研究展望}

辻＼cjkstart博文，日恵井佳子，若林信行，白井裕三

\begin{abstract}
It is very important to understand the mechanisms of the slagging and the fouling on the pulverized coal combustion in order to avoid the troubles due to ash depositions on furnace walls and tube surfaces. This review shows the fundamentals of ash deposition mechanisms and indices for predicting slagging and fouling propensities based on bulk compositions of coal. The new evaluation methods are also summarized, which use advanced coal analyses. A lot of indices based on bulk compositions of coal are widely used for prediction of ash depositions. These are, however, not applicable to determine the positions, where ash depositions occur, and the effect of combustion conditions. The advanced method by use of the numerical simulation techniques, which incorporate the models of ash formation process and ash deposition behavior during pulverized coal combustion, is desirable for precise evaluation.
\end{abstract}

\section{Key Words}

Pulverized coal combustion, Ash deposition, Slagging, Fouling

\section{1. はじめに}

微粉炭火力発電は，エネルギーセキュリティなどの観 点から, 今後も重要な電源のひとつと位置づけられてい $3^{1)}$ 。このため微粉炭火力の高度化に向けて，利用炭種の 拡大，環境污染物質排出量の一層の低減および石炭灰の 利用用途の拡大など，様々な研究開発苜が行われている。 これらに加え, 地球温暖化対策として, 各種バイオマス の混焼 ${ }^{2}$ や，さらなる発電効率向上を目指し蒸気条件改 善のための材料開発1314) も進められている。したがって, 今後微粉炭火力では，燃料種や運用条件が多種・多様化 する傾向にある。

微粉炭火力で一部の石炭を利用した際に，石炭中の灰 分がボイラの伝熱面に付着（スラッギングおよびファウ リング）し，伝熱効率の低下やガス流れの閉塞，これら による脱硝装置入口温度の上昇，およびボイラチューブ の損耗などの扊付着事象が発生している。この扊付着事 象により，利用炭種や発電所の運用に制限が生じる場合 があり，その回避は微粉炭火力の安定運転を行う上で極

Energy Engineering Research Laboratory

Central Research Institute of Electric Power Industry

2-6-1 Nagasaka, Yokosuka-shi, Kanagawa 240-0196, Japan
めて重要である。

微粉炭燃焼時のスラッギングとファウリングについて は，国内外で古くから研究が行われており，伝熱面への 灰粒子の付着性を石炭中の灰組成等から判別する評価法 が提案されている。わが国の微粉炭火力では, 前述のよ うに利用炭種の拡大や, 各種バイオマス等の導入が急速 に進展すると予想され，これらの燃料の扊粒子の付着性 評価も今後重要となる。

本報では，以上のような状況を踏まえ，微粉炭燃焼時 のスラッギングおよびファウリングについて，その発生 メカニズムと既存の評価法を概説する。あわせて，評価 法の高度化における課題を展望する。

2. スラッギングとファウリングの発生メカニズムおよ び評価法

わが国の微粉炭火力で利用されている石炭には，おお よそ数\%～20\%の灰分が含まれている。この灰分がボイ ラや排煙処理装置などに付着し，運転に影響をおよぼす

(財)電力中央研究所 エネルギー技術研究所

广 240-0196 横須賀市長坂 2-6-1 
場合がある。ボイラで生じる灰粒子の付着のうち，ふく 射伝熱面で生じるものをスラッギング, 対流伝熱面で生 じるものをファウリングとそれぞれ呼ぶ。図 1 にスラッ ギングおよびファウリングの発生領域と付着状況の写真 を示す。ファウリングについては，ガス温度が高い領域 (約 $900^{\circ} \mathrm{C}$ 以上) で生ずる高温ファウリングと低い温度領 域 (約 $900^{\circ} \mathrm{C}$ 未満) で生ずる低温ファウリングとに分けら れる。灰粒子の伝熱面への付着は, 伝熱効率の低下やガ ス流れの閉塞，これらによる脱硝装置入口温度の上昇，ボ イラチューブ等の損耗，および付着物の落下による炉底 部の損傷などを生じることがある7) 9)。

スラッギングとファウリングは, ボイラ内の乱流燃焼 場内での灰粒子の昇温・冷却, 揮発・凝縮, 溶融・固化, 伝熱面への移動・到達拧よび付着後の化学変化・焼結な どを含む極めて複雑な現象であり，その解明のため多数 の研究が様々な観点から行われている ${ }^{8)}$ 19)。これらの研 究により, 灰粒子の伝熱面への付着は, 石炭抢よび死分

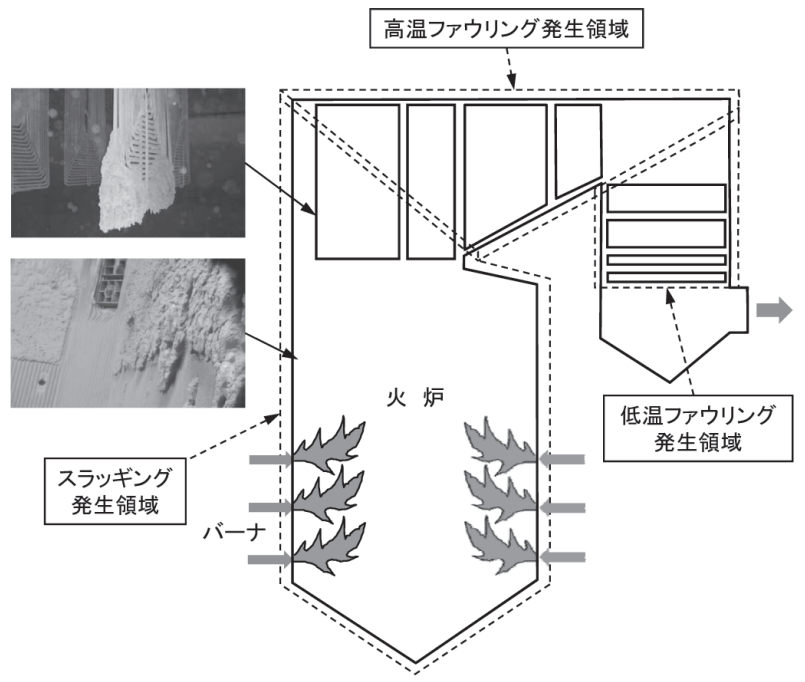

図 1 スラッギングとファウリングの発生領域および発生状況 の写真（文献 5）6）を参考に作成）

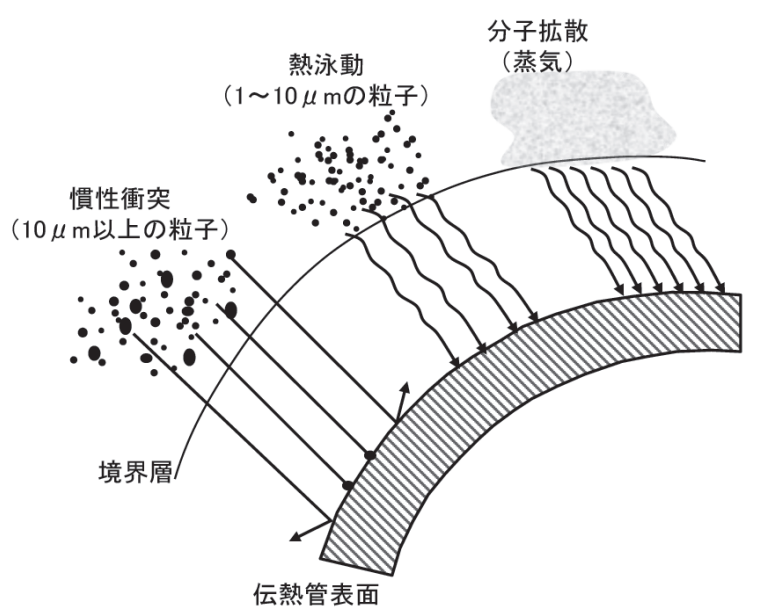

図 2 伝熱面への灰粒子の移動・到達機構（文献 7）を参考に作 成）
の組成・形態，ボイラ内の燃焼・流動状沉および伝熱面 の物理・化学的状態などに影響されることが明らかにさ れている。

伝熱面への灰粒子の移動・到達機構の概念を，図２に 示す。灰粒子の移動・到達は, 図示のように, (1)約 $10 \mu \mathrm{m}$ 以上の粒子による慣性衝突, (2) $1 \sim 10 \mu \mathrm{m}$ 程度の粒子の 熱泳動，扣よび(3)伝熱面近傍で泠却され凝縮したサブミ クロン粒子の拡散，によって生ずる。

\section{1 スラッギング}

\section{1 .1 発生メカニズム}

スラッギングは，火炎からのふく射を受ける伝熱面に 生じる灰粒子の付着のことであり，水冷壁，ふく射型スー パーヒータ, バーナ出口部およびボイラ下部ホッパ部等 に生ずる。微粉炭然焼時は，火炎内の粒子温度が $1500^{\circ} \mathrm{C}$ 以上となり，灰粒子の溶融が生ずる。このうち, $\mathrm{Na}, \mathrm{Ca}$ およびFeを含むケイ酸塩化合物などを含む溶融が進行し やすい灰粒子が伝熱面に移動・到達して, 付着層の形成 が始まる。この付着層の成長により, 層内の温度勾配が 高くなる。これにともない, 付着層の表面は高温となり, 著しい粘着性・溶融性を示すようになる。その付着層に 新たに到達した死粒子は, その灰粒子自身が粘着性・溶 融性を示さなくても捕捉され, 付着層の成長が加速され る。したがって, 十分発達したスラグ層では, その組成 が石炭中の灰組成と概ね近似する例が報告8)されている。 スラグ層の構造の概念図を，図 3 に示す。

スラッギングの主な発生域である水冷壁の表面温度は, 通常 $300 \sim 550^{\circ} \mathrm{C}$ 程度で灰粒子の融点以下である。した がって, 十分に発達したスラグ層では, 水冷壁表面付近 の付着物は溶融しておらず，スラグ層の火炉側表面が溶 融した状態である。スラグ層は, その厚さにより, 次の 4 つに分類されることがある ${ }^{8)}$

(1)流動スラグ (running slag)

(2)厚さが $2.5 \mathrm{~cm}$ 以下の小規模な付着

(3)厚さが $2.5 \sim 7.5 \mathrm{~cm}$ の中規模な付着

(4)厚さが $7.5 \mathrm{~cm}$ を超える大規模な付着

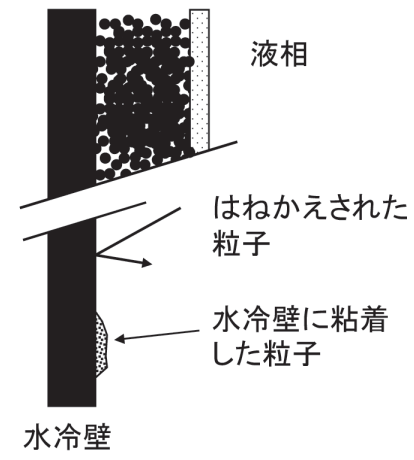

図 3 スラッギングによる灰粒子の付着層の構造（文献 7) を参 考に作成） 
この分類では(1)から(4)になるにしたがい，スラッギン グがボイラの運転・管理におよぼす影響が顕著になると 考えられる。

またスラグ層は，その物理的状況の観点から，次のよ うに分類される場合もある ${ }^{8)}$ 。

(1)高い流動状態を示し，流れやすい。

(2)溶融し，下部へゆっくりと流動する。

(3)溶融しており表面が丸みを帯びている，あるいは溶 融しているが下部への流動はない。

(4)溶融しておらず (dry deposit)，層のエッジがシャー プである。

\section{1 .2 評価法}

スラッギングの評価指標を，表 1 に示す。評価指標は， 大まかに，(1)石炭中の灰組成から導出するもの，(2)石炭 灰の溶融性から導出するもの，および(3)石炭灰の焼結性 から導出するものに，分類される。ほとんどの指標が，定 義式に従い評価值を算出し，その值に基づきスラッギン グ性を小からシビアに区分する。

灰組成から導出する指標には，灰アルカリ率（Base/ Acid 比) や, $\mathrm{SiO}_{2}, \mathrm{Fe}_{2} \mathrm{O}_{3}$ および $\mathrm{CaO}$ などの含有率に着目 したものがある。石炭灰の溶融性から導出する指標は, 石 炭灰の粘性や融点などから求めるものである。石炭灰の 焼結性から導出する膠着度は，近年提案されたもの ${ }^{5) 17718)}$ で，治金の分野で用いられるラトラ試験により，スラグ 灰を評価する方法である。表 1 の指標は，必ずしも，同 様の設備・手法を用いて確立されたものではなく，また 評価基準の判定方法も明らかにされたものが少なく，指 標を使用する祭には留意が必要である。

表 1 には，わが国の微粉炭火力発電所等においてス ラッギングの評価に良く用いられる指標を示した。Base/ Acid比，スラッギングファクタおよび死融点等が一般的 に用いられている。ただし，これらの指標の精度につい ては，公表されたものが少なく，明確にされていない。

\section{2 ファウリング}

\section{2 .1 発生メカニズム}

ファウリングの付着層構造の概略を, 図 4 に示す。ファ

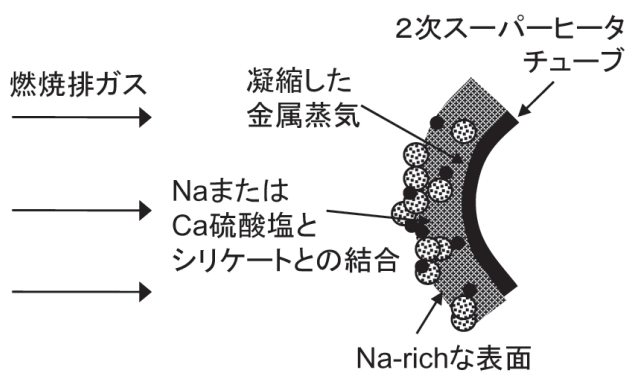

(a) 高温ファウリング
ウリングは，ガス温度が約 $900^{\circ} \mathrm{C}$ 以上の高温ファウリング (主にスーパーヒータとリヒー夕等の領域) と, 約 $900^{\circ} \mathrm{C}$ 未満の低温ファウリング(主にエコノマイザ等の領域)に 分けられる。

ファウリングは，燃焼時に一旦揮発した後，凝縮した 灰分粒子が伝熱面に付着して形成される薄い層から始ま る。これは，主に Na，K，Caおよびこれらの硫酸塩で構 成される。アルカリ金属は，ガス層で酸化物や水酸化物 となり， $\mathrm{SO}_{3}$ と反応し硫酸化物となる。これらが，低融点 の共晶物となり，粘着性のある付着物として伝熱面表面 に付着する。

高温ファウリングは，硫酸塩が安定に存在する温度よ り高温の領域で生じる。伝熱表面の付着層に，粒子が慣 性力等で衝突すると，粒子表面でアルカリ溶融が生じ，粒 子が粘着性となる。付着物が成長すると，焼結が生じ，付 着層内の温度勾配が増加する。この際，ケイ酸塩溶融物 がバインダとなり，焼結が生じやすくなる。この結果，付 着層の表面温度が上昇し，表面は液層となるか，付着性 を有するようになる。これにより，最終的に付着性のな い粒子まで伝熱面に付着する。一方，低温ファウリング では，主に $\mathrm{CaSO}_{4}$ などの硫酸塩がバインダとなり，粒子 の付着層を成長させる。その後の付着層の成長過程は，高 温ファウリングと同様である。高温ファウリングと低温 ファウリングでは，付着層内の位置により，粒子径や組 成が大きく異なる。

高温ファウリングと低温ファウリングでは，図 4 に示 すように，伝熱面の流れと衝突する領域（ボイラチュー ブの上流側)で，付着層がガス流れと逆方向に成長する。 一方，図 5 に示すように，ボイラチューブの下流側にも

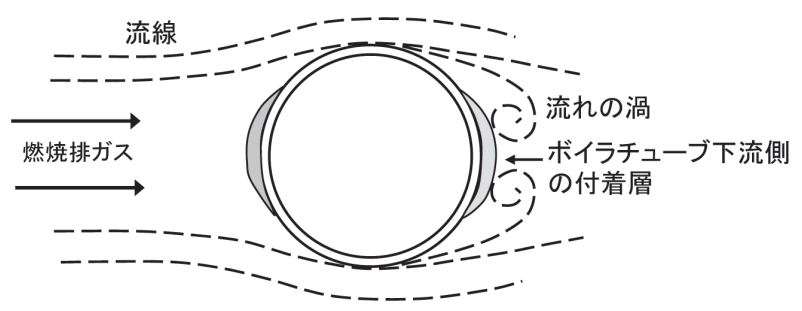

図 5 ボイラチューブの下流側に生ずる灰粒子の付着層（文献 8）を参考に作成)

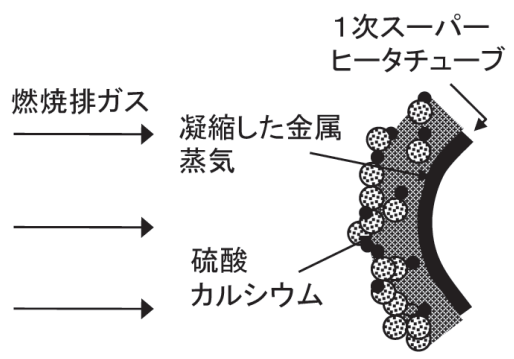

(b) 低温ファウリング

図 4 ファウリングによる灰粒子の付着層の構造（文献 7) を参考に作成） 


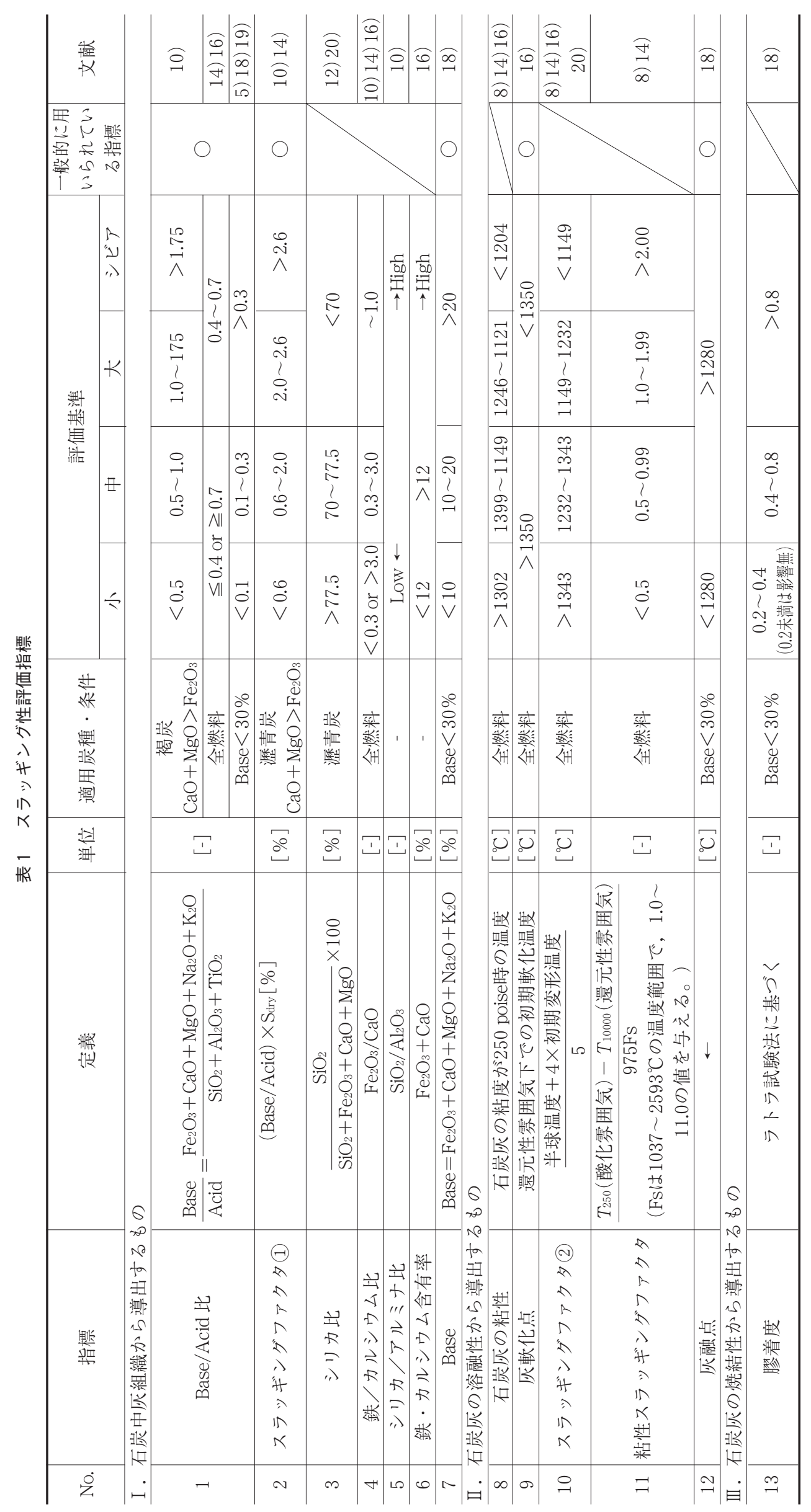


付着が発生する場合もある ${ }^{8)}$ 。この付着は，石炭中の $\mathrm{Na}$ が主体の粒子がボイラチューブの下流側に生ずる流れの 渦によってボイラチューブ表面に到達し, 生ずる。この 灰粒子の付着は, 瀝青炭の燃焼時にも見られるが, $\mathrm{Na}$ 含有 率が高い褐炭の燃焼時に特に生じやすいとされている ${ }^{8)}$ 。

\subsection{2 評価法}

ファウリングの評価指標は，表 2 に示すように，(1)石 炭中の灰組成から導出するもの, (2)石炭灰の溶融性から 導出するもの，および(3)石炭灰の焼結性から導出するも のに，スラッギングの評価指標と同様の分類ができる。 ファウリングの指標も，定義式に従い評価值を算出し，そ の值に基づきファウリング性を小からシビアに区分する。 ただし，高温ファウリングと低温ファウリングを区別し て評価する指標は見られない。

石炭中の扊組成から導出する指標が，9 種類と最も多 い。スラッギングの評価指標では灰の溶融性に着目した 指標が多いのに対して，ファウリングの評価指標ではNa やKの含有率に着目したものが多い。これは，前項で述 ベたように，ファウリングが凝縮したアルカリ金属等か ら生じることを反映していると考えられる。ファウリン グによる灰粒子の付着層は，局所的に溶融していると考 えられるが，付着層全体に溶融は生じていない。このた め，ファウリングの場合，石炭灰の溶融性から導出する 指標の数は，スラッギングに比べて少ない。石炭灰の焼 結性から導出する指標も2 種類見られる。ファウリング の評価指標も，必ずしも，同様の設備・手法を用いて確 立されたものではなく，また評価基準の判定方法も明ら かにされたものが少なく，指標の使用時には注意が必要 である。

表 2 には, わが国の微粉炭火力発電所等においてファ ウリングの評価に主に用いられる指標を示した。アルカ リ金属を用いる指標が一般的に用いられているが，その 精度等は, 公表されたデータがほとんどなく, 明確にさ れていない。

スラッギングおよびファウリングでは，伝熱面での灰 粒子の初期付着層に別の粒子が到達し, 溶融 - 焼結しな がら付着層が成長する。初期付着層は短時間で形成され るが，灰粒子の付着層の成長に関与する焼結は長い時間 を要すると考えられる。

初期付着層に関しては，大学等の研究機関により，小 型の試験炬や落下型電気炉等を用いた多くの研究が実施 されている。Su ら 16) 22) 24) は, 試験炉で多数の石炭を同 一条件で然焼し, 初期付着層に関する詳細な研究を行っ ている。その結果，初期付着層の形成には，FeおよびNa を主に含む粒子が深く関与すると結論付けられている。

著者らは，表 1 および表 2 のうち石炭中の灰組成から 導出する指標と Suらの試験結果の関係を評価・検討した
が，いずれの指標に対しても明確な相関性は見られな かった。すなわち, 石炭中の灰組成から導出する指標の, 初期付着に対する評価精度はあまり高くないと考えられ る。付着層の溶融 - 焼結性が, 初期付着層の形成過程と 同様にスラッギングとファウリングに関する重要なプロ セスであることが示唆される。灰粒子の焼結性は，長い 時間を要する現象であるため，十分な検討が行われてい るとは言い難い。今後，付着層の焼結に関する検討が必 要であると考えられる。

\section{3 高度分析技術を用いた評価法}

石炭中の死粒子は，石炭中に不均一に分散して存在し ている。石炭粉砕後の灰分は，炭素質とイオン結合して いるもの，炭素質に取り込まれている灰粒子 (Included粒 子)，および炭素質に取り込まれておらず，外周部の一部 あるいは全てが周囲ガスに晒されている扊粒子 (Excluded 粒子) に分類される。

これらの灰粒子の燃焼時の変化過程を，図 6 に示す。本 図のように，灰粒子の燃焼時の変化過程は，その存在形 態によって大きく異なる。炭素質とイオン結合した無機 物は，揮発・凝縮および合一等を経て，燃焼灰粒子（フ ライアッシュ) となる。Included粒子は，チャー内での灰 粒子の合一，チャー表面からの鉱物の脱落およびチャー の分裂などを生じながら，フライアッシュを生成する。一 方，Excluded 粒子は，鉱物単体粒子の分裂，溶融を経て フライアッシュとなる。一部のExcluded粒子は，内部に ガスを含んだ中空灰粒子となる。フライアッシュの粒径 分布は，鉱物に由来する $0.5 \mu \mathrm{m}$ 以上の双峰分布に，無機 物の揮発・凝縮過程で生成する $0.1 \mu \mathrm{m}$ 程度にピークを持 つ単峰分布を組み合わせたものとなる ${ }^{8)}{ }^{25)}$ 。

以上のように，石炭中灰粒子の存在形態によって，然 焼時の粒子の揮発・凝縮, 溶融状態および粒径が異なる ため，灰粒子の付着挙動も変化する。したがって，石炭 中灰粒子の存在形態の把握はスラッギングとファウリン グの評価において重要である。石炭中灰粒子の存在形態 の分析手法として, CCSEM (Computer Controlled Scanning Electron Microscopy) などが一般的に用いられている。な お，第 2 章の表 1 および表 2 に示した指標は，いずれも 石炭のバルクとしての特徵を表しており，石炭中扊粒子 の存在形態の影響を考慮したものではなく，留意が必要 である。

これに加え，固気反応の熱平衡計算技術の進歩等によ り, 微粉炭燃焼時の灰粒子の相変化, ボイラ内のガス温 度およびガス組成等をある程度の精度で把握することが 可能になった。これらの技術と石炭中死粒子の存在形態 の分析結果を組み合わせた，スラッギングとファウリン グの解析ツールが，表 3 に示すように提案されている。現 在，本表に示す 4 種類のツールが開発され，スラッギン 


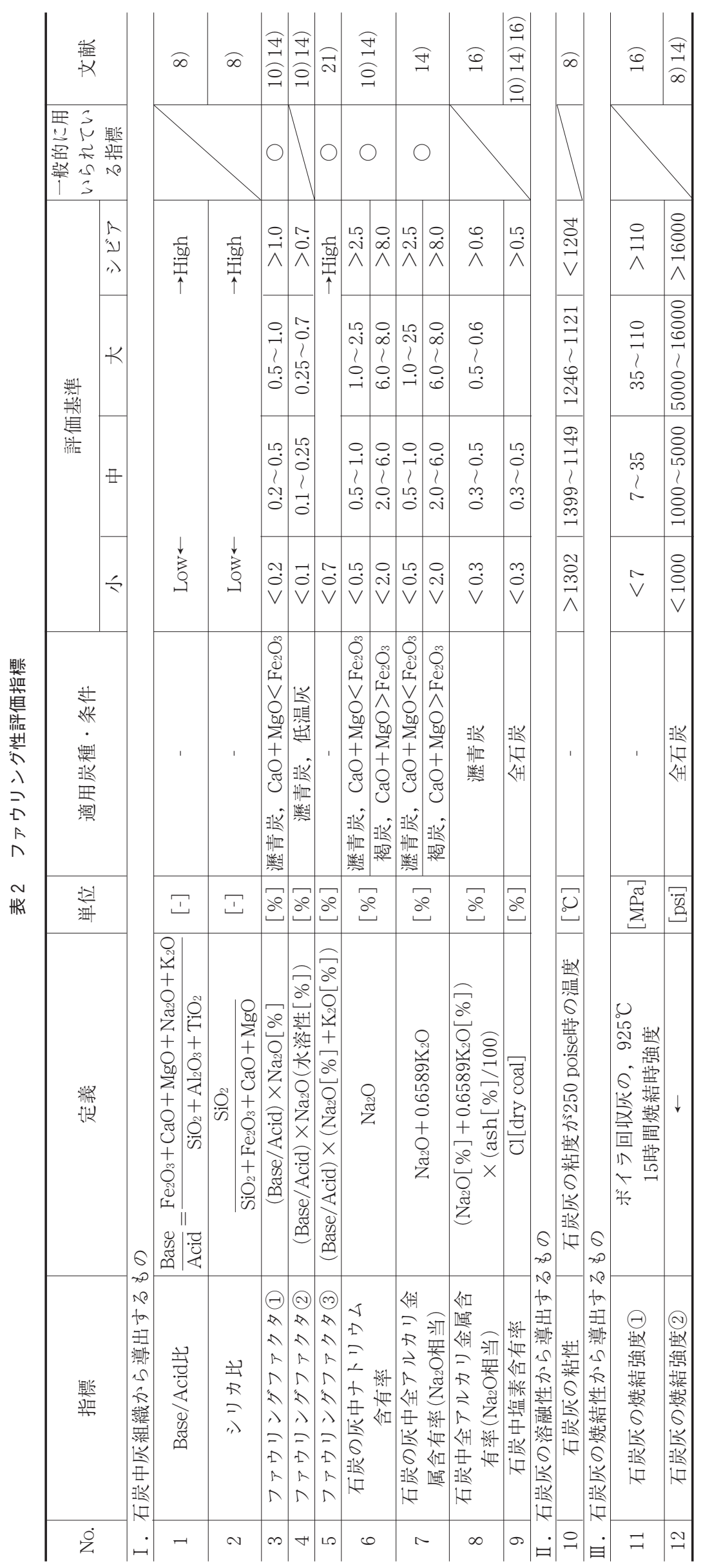




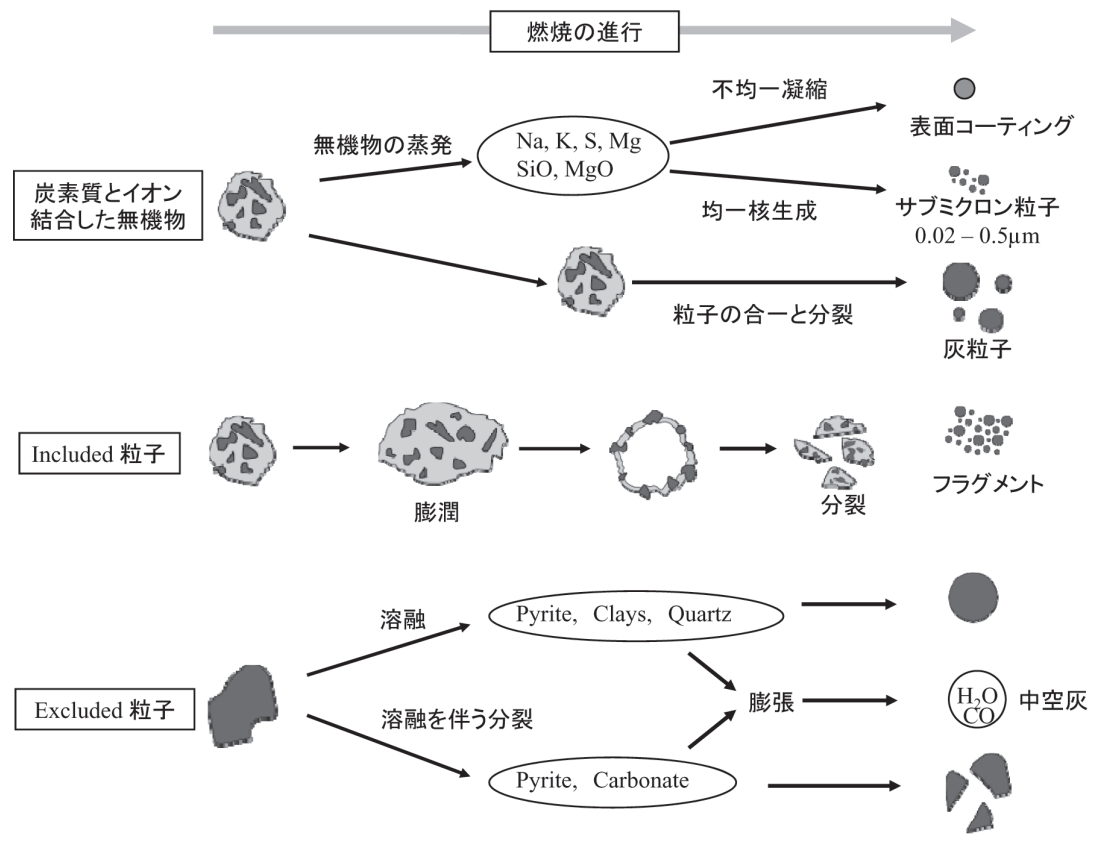

図 6 微粉炭燃焼時の灰粒子の変化過程（文献 7) を参考に作成）

表 3 高度分析に基づくスラッギング・ファウリングの解析ッール

\begin{tabular}{|c|c|c|c|}
\hline ツール名 & $\begin{array}{l}\text { 開発組織 } \\
\text { (国名) }\end{array}$ & 入力項目 & 評価項目 \\
\hline $\begin{array}{l}\text { PCQUEST }{ }^{26)} \\
\text { (Predictive Coal Quality Effects } \\
\text { Screening Tool) }\end{array}$ & $\begin{array}{c}\text { Energy \& Environmental Re- } \\
\text { search Center (EERC) } \\
\text { (米国) }\end{array}$ & $\begin{array}{l}\text { - 石炭性状 } \\
\text { ·鉱物組成 } \\
\text { - 燃燒条件 }\end{array}$ & $\begin{array}{l}\cdot \text { スラッギング性 } \\
\cdot \text { 高温ファウリング性 } \\
\cdot \text { 低温ファウリング性 } \\
\cdot \text { 配管腐食性 } \\
\cdot \text { 石炭粉砕性 } \\
\cdot \text { ・スートブロアタイミング他 }\end{array}$ \\
\hline $\begin{array}{l}\text { ADLVIC }{ }^{27)} \\
\text { (Ash Deposition Local Viscosity, } \\
\text { Index of reflection, and } \\
\text { Composition) }\end{array}$ & $\begin{array}{c}\text { Sandia National Laboratories } \\
\text { (米国) }\end{array}$ & \begin{tabular}{|l}
$\cdot$ 石炭性状 \\
·鉱物組成 \\
・ ボイラサイズ・運転条件 \\
など
\end{tabular} & $\begin{array}{l}\cdot \text { 灰付着量と組成 } \\
\cdot \text { 灰付着箇所 } \\
\cdot \text { 付着速度 } \\
\text { ·付着物の硬度 } \\
\text { ·付着物の除去性（付着強度） }\end{array}$ \\
\hline PSI Slagging Advisor ${ }^{28)}$ & $\begin{array}{l}\text { PSI Power Serve } \\
\text { (米国) }\end{array}$ & $\begin{array}{l}\cdot \text { 石炭性状 } \\
\cdot \text { CCSEM 測定結果 }\end{array}$ & $\begin{array}{l}\text { ·燃焼灰の粒径や組成 } \\
\text { ·付着物の粘性 } \\
\text { ·灰付着位置と付着量 }\end{array}$ \\
\hline 石炭評価システム 29) 30) & $\begin{array}{r}\text { 出光興産 (株) } \\
\text { (日本) }\end{array}$ & $\begin{array}{l}\cdot \text { 石炭性状 } \\
\cdot \text { ボイラのサイズ・構造, } \\
\text { 運転条件 } \\
\cdot \text { CCSEM 測定結果等 }\end{array}$ & $\begin{array}{l}\cdot \text { ·石炭使用可否 } \\
\cdot \text { ・ スラッギング性 } \\
\cdot \text { 最適混炭条件 } \\
\cdot \text { 炉内温度分布・ガス濃度分布 } \\
\cdot \text { NOx 濃度, 灰中未然分濃度 } \\
\cdot \text { ·運転条件変化時の上記項目 }\end{array}$ \\
\hline
\end{tabular}

グとファウリングの評価に用いられている。

これらのツールの代表例として, PSI Slagging Advisor の解析フローを図 7 8) に示す。本ツールでは, 従来の石 炭の分析結果に加えて, CCSEMによる灰粒子の存在形態 の分析結果を使用する。これらと灰粒子の燃焼時の変化 過程モデルおよび簡略化されたボイラ内の流れモデルな どから，スラッギング性を評価する。
3. スラッギングおよびファウリングに関する今後の研 究展望

第 2 章の表 1 および表 2 に示した指標は, いずれも石 炭のバルク組成等から灰粒子の付着性を評価するもので ある。これらの指標では, 従来から用いられている石炭 の分析手法から灰粒子の付着の予測ができるため, 簡易 に評価を行うことができる。このため, これらの指標に 関して, 微粉炭火力等では多数の知見が蓄積されており, 今後も活用されていくと考えられる。ただし，これらの 


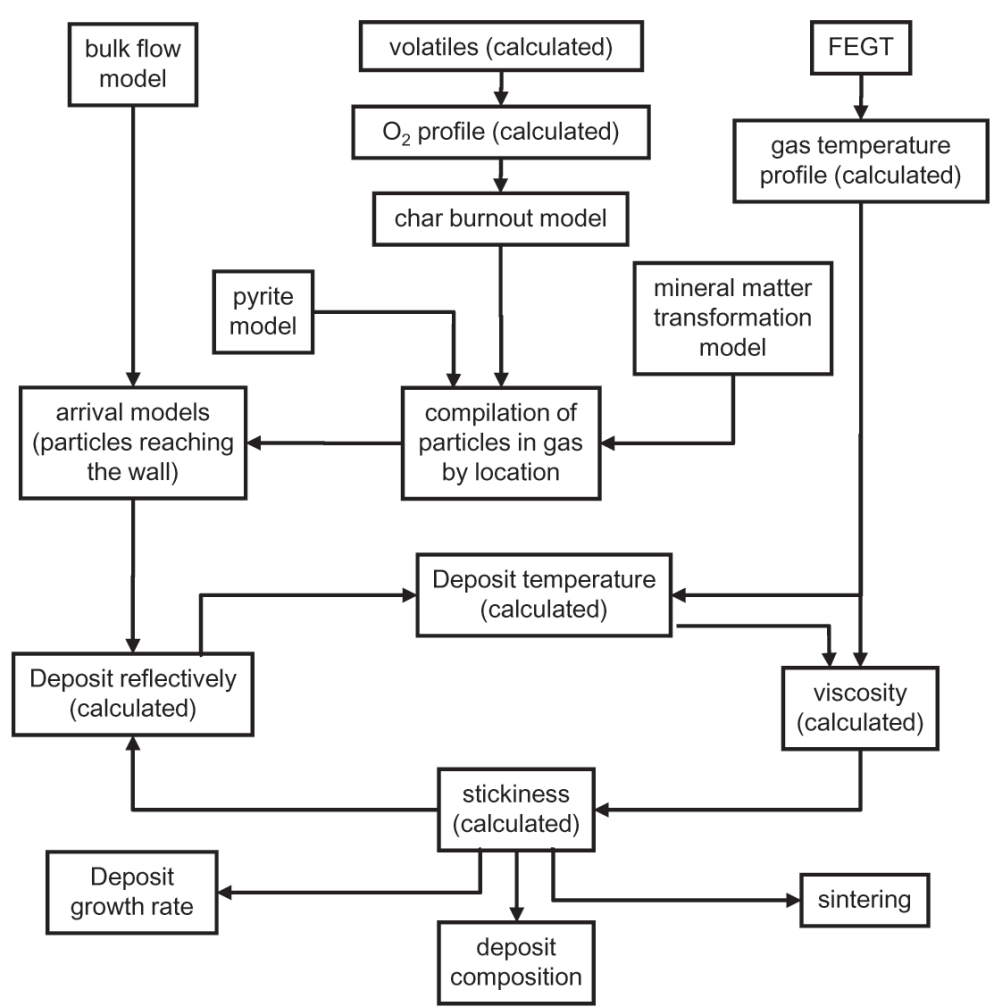

図 7 PSI Slagging Advisor の解析フロー8)

指標は, 燃焼時の挙動が大きく異なる石炭中灰粒子の存 在形態を考慮したものではない。また，灰粒子の付着箇 所の特定や燃焼条件の影響評価を行うことができない。 したがって，これらの指標の今後の大幅な進展は望めな いと考えられる。

一方, 石炭中灰粒子の存在形態の分析結果や簡略化さ れたボイラ内の流れモデルなどを用いる，新たな解析 ッールが開発されている26) 30)。これらのツールでは，石 炭の高度な分析技術などを必要とするが，灰粒子の変化 過程等を考慮した，より精度の高い評価が可能である。た だし，これらの解析ツールについては，精度検証等が十 分になされているとは言い難く, 今後の検討が重要であ ると考えられる。

スラッギングおよびファウリングのより高精度な評価, 例えば，運転条件等の变化時における死付着事象発生の 有無の判別や灰粒子の付着発生箇所の特定を行うために は, 微粉炭の燃焼シミュレーションの活用が不可欠であ ると考える。このためには, 既存の燃焼シミュレーショ ン技術へ灰粒子の変化過程および伝熱面への付着過程の モデルを導入する必要がある。図 6 の灰粒子の変化過程, および図 2 の灰粒子の付着過程のすべてをモデリングす ることは，計算機の負荷や実用性の面から，現状では有 効ではないと考えられる。スラッギングやファウリング に深く関連するプロセスの抽出とそのモデル化が不可欠 である。

灰粒子の変化過程については, 燃焼後のフライアッ
シュの粒径分布の予測手法が，いくつか提案 ${ }^{31)}$-33) され ており，その一部はスラッギングやファウリングに関連 する灰粒子の変化過程のモデル化にも活用できると考え られる。灰粒子の分裂のみを考慮した，固体燃料の燃焼・ ガス化過程のシミュレーションが行われ, 灰粒子の分裂 が粒子軌跡, ガス温度分布およびガス組成分布等に影響 することが報告されている ${ }^{34)}$

スラッギングによる扊粒子の付着に関しては, 商用の 微粉炭燃焼ボイラを対象に, 死粒子の付着が死粒子の粘 度によって決定されるモデルを用いたシミュレーション が行われている35) 36)。Plazaら ${ }^{37)}$ は, 灰粒子の付着が扊粒 子の固層と液層の割合によって決定されるモデルを用い て，スラッギングと高温ファウリングのシミュレーション を実施している。これらの研究では, シミュレーション結 果と試験デー夕の比較評価が不十分であり, シミュレー ションの精度が十分に明らかとなっていない。Maら ${ }^{38}$ は, スラッギングとファウリングのシミュレーションを実施 し，その精度を商用の微粉炭燃焼ボイラを用いて評価し ているが，付着過程等のモデルが明確にされておらず，今 後の検証が必要である。

以上のように，スラッギングとファウリングのシミュ レーションは現在，灰粒子付着過程などのモデルの検討 とその精度評価が行われている段階である。今後，スラッ ギングとファウリングの現象解明が進展して，新たなモ デルが開発され，実験との対比等を通じてシミュレー ション技術の高度化が図られるものと考えられる。 


\section{4. おわりに}

本報では，微粉炭燃焼時のスラッギングおよびファウ リングに関し，その発生メカニズムおよび既存の評価法 を概説するとともに，評価法の高度化における課題を展 望した。石炭のバルク組成等から，スラッギングやファ ウリングを評価する指標が多数あり，微粉炭火力等で用 いられている。ただし，これらの指標では燃焼条件の影 響評価や灰粒子の付着箇所の特定ができないなどの課題 がある。また，これらの指標は燃焼時の挙動が大きく異 なる石炭中灰粒子の存在形態を考慮したものではない。

他方，CCSEM等の石炭の高度分析技術を用い，石炭中 灰粒子の存在形態などを考慮した新たな解析ツールの開 発がなされている。これらの解析ツールは，今後の進展 が期待されるが，まずは精度の検証が重要であると考え られる。

スラッギングやファウリングの評価法を一層高度化す るためには，燃焼条件の影響把握や灰粒子の付着箇所の 特定などができるようにする必要がある。このためには, 燃焼時の灰粒子の変化過程と伝熱面への付着過程などの モデルを高度化し，それらを燃焼シミュレーションへ導 入した新たな解析技術の開発が望まれる。

\section{文 献: References}

1）持田勲編，クリーン・コール・テクノロジー，(工業 調査会)，(2008）：Mochida, I. ed., Clean Coal Technology, (Kogyo Chosakai Publishing, Inc.),(2008)

2) 中村孝洋，中川賢剛，田中誠，鈴木昭雄，金氏武，木 本政義，火力原子力発電，57,839(2006)：Nakamura, T., Nakagawa, K., Tanaka, M., Suzuki, A., Kaneuji, T., Kimoto, M., The Thermal and Nuclear Power, 57, 839 (2006)

3）佐藤幹夫，日エネ誌，86, 304-309 (2007)：Sato, M., $J$. Jpn. Inst. Energy, 86, 304(2007)

4）佐藤幹夫，屋口正次，田中良典，岩崎淳，福田雅史， 斎藤英治, 中川博勝, 椎橋啓, 和泉栄, 火力原子力発 電, 57, 821 (2006) : Sato, M., Yaguchi, M., Tanaka, Y., Iwasaki, J., Fukuda, M., Saito, E., Nakagawa, H., Shiibashi, A., Izumi, S., The Thermal and Nuclear Power, 57, 821 (2006)

5）毛利慎也，茂田潤一，鈴木幸平，福島仁，火力原子力 発電, 56, 26 (2005) : Mouri, S., Shigeta, J., Suzuki, K., Fukushima, H., The Thermal and Nuclear Power, 56, 26 (2005)

6) (独)新エネルギー・産業技術総合開発機構, 平成19年 度成果報告書「国際石炭利用対策事業 クリーン・コー ル・テクノロジー実証普及事業(案件発掘調査)ナノ石 炭添加剂利用技術導入可能性調査」, (2008)

7）二宮善彦，日工齐誌，75, 433(1996) : Ninomiya, Y., J. Jpn. Inst. Energy, 75, 433(1996)

8) Couch, G., Understanding slagging and fouling during pf combustion, IEA COAL RESEARCH,(1994)
9) Williams, A., Pourkashanian, M., Jones, J. M., Skorupska, N., Combustion and Gasification of Coal, (Taylor \& Francis, Inc.), pp. 158-160 (2000)

10）寺前剛，山下亨，日エネ誌, 76, 988(1997)：Teramae, T., Yamashita, T., J. Jpn. Inst. Energy, 76, 988(1997)

11) Wall, T. F., Lowe, A., Wibberley, L. J., Stewart, McC., Prog. Energy Combust. Sci., 5, 1(1979)

12）篠崎貞行，谷口一徳，燃協誌，68，1020(1989)： Shinozaki, S., Taniguchi, K., Nenryo Kyokaishi, 68, 1020 (1989)

13) Smoot, L. D. ed., Fundamentals Coal Combustion for Clean and Efficient Use, Coal Science and Technology 20, (ELSEVIER), (1993)

14) Bryers, R. W., Prog. Energy Combust. Sci., 22, 29 (1996)

15) Heap, M. P., Kramlich J. C., Pershing, D. W., Pohl, J. H., Richter, W. F., Seeker, W. R., Effects of Coal Quality on Power Plant Performance and Costs Volume 4: Review of Coal Science Fundamentals, Project 2256-1, (EPRI), (1986)

16) Su, S., Combustion Behaviour and Ash Deposition of Blended Coals, Dr. Thesis, The University of Queensland, (1999)

17）毛利慎也，福島仁，茂田潤一，羽嶋範昭，蔵田良正， 山崎英幸，火力原子力発電，59, 601 (2008)：Mouri, S., Fukushima, H., Shigeta, J., Hajima, N., Kurata, Y., Yamazaki, H., The Thermal and Nuclear Power, 59, 601 (2008)

18）毛利慎也，茂田潤一，鈴木孝平，福島仁，石川島播磨 技報，45, 36 (2005)：Mouri, S., Shigeta, J., Suzuki, K., Fukushima, H., Ishikawajima-Harima Gihou, 45, 36 (2005)

19）長沼宏，成瀬一郎，宮内良樹，河合隆之，伊藤正，三 木良治，相澤威一郎，狩野勝広，日工六誌，86, 102 (2007) : Naganuma, H., Naruse, I., Miyauchi, Y., Kawai, T., Itoh, T., Miki, Y., Aizawa, I., Karino, K., J. Jpn. Inst. Energy, 86, $102(2007)$

20) Bott, T. R., Proc. Eng. Foundation Conf., Palm Coast March 10-15, 499 (1991)

21）日本機械学会編，燃焼工学ハンドブック，(日本機械学 会), (1995)：The Japan Society of Mechanical Engineers ed., JSME Combustion Handbook, (The Japan Society of Mechanical Engineers), (1995)

22) Su, S., Pohl, J. H., Holcombe, D., Hart, J. A., Fuel, 80, 1351 (2001)

23) Su, S., Pohl, J. H., Holcombe, D., Hart, J. A., Combustion Sci. and Tech., 165, 129 (2001)

24) Su, S., Pohl, J. H., Holcombe, D., Fuel, 82, 1653 (2003)

25) Markowski, G. R., Ensor, D. S., Hooper, R. G., Carr, R. C., Environ. Sci. Technol., 14, $1400(1980)$ 
26) http://www.netl.doe.gov/technologies/coalpower/ advresearch/pubs/ARSS-016_4P.pdf

27) EPRI, Technology Review, "Validation of fireside performance tools for coal combustion”, (2000)

28) Baxter, L. L., DeSollar, R. W., Fuel, 72, 1411 (1993)

29) http:/www.idemitsu.com/energy/environment/ system.html

30）山下亨, 日本エネルギー学会, 第42回石炭科学会議発 表論文集, 57(2005)：Yamashita, T., Jpn. Inst. Energy, the 42th Conference of Coal Science, $\mathbf{5 7}$ (2005)

31) Barta, L. E., Horvath, F., Beer, J. M., Sarofim, A. F., TwentyThird Symposium (International) on Combustion/The Combustion Institute, 1289(1990)

32） Barta, L. E., Toqan, M., Beer, J. M., Sarofim, A. F., Twenty-
Fourth Symposium (International) on Combustion/The Combustion Institute, 1135 (1992)

33) Yan, L., Gupta, R .P., Wall, T. F., Fuel, 81, 337 (2002)

34) Syred, N., Kurniawan, K., Griffiths, T., Gralton, T., Ray, R., Fuel, 86, 2221 (2007)

35) Fan, J. R., Zha, X. D., Sun, P., Cen, K. F., Fuel, 80, 645 (2001)

36) Fang, Q., Wang, H., Wei, Y., Lei, L., Duan, X., Zhou, H., Fuel Processing Technology, 91, 88 (2010)

37) Plaza, P., Griffiths, A. J., Syred, N., Rees-Gralton, T., Energy and Fuels, 23, 3437 (2009)

38) Ma, Z., Iman, F., Lu, P., Sears, R., Kong, L., Rokanuzzaman, A.S., McCollor, D. P., Benson, S. A., Fuel Processing Technology, 88, 1035 (2007) 